\title{
1107 定容燃焼容器によるエンジン用熱流束計の実験的研究
}

\section{Experimental Study of Style Heat Flux Sensor for Engine with Constant Volume Combustion Bomb}

正 長瀬 慶紀 (宮崎大) O学 根井 郁拓（宮崎大院）正 田坂 英紀 (官崎大)

Hidenori TASAKA, Miyazaki University, Gakuenkibanadai Nishi 1-1, Miyazaki Ikuhiro NEI, Miyazaki University Graduate School

Yoshinori NAGASE, Miyazaki University

Kay words; Quantitative Measurement, Heat Flux Probe, Gas Side Heat Flux, Wall Side Heat Flux

\section{1. 粕論}

内㜣機関は，環境問題が深刻化し，従来にも增して排出 ガスの浄化と高効率化が要求されている. その方法の一つ として筒内ガス流動を利用し熱奻率や燃焼性の向上が図ら れている.ガス流動の影響を受ける燃焼状態では，既燃ガ スと燃焼室壁面との間の熱后達も促進され，燃焼室壁面一 の熱流束, 冷却損失が增大し出力低下などを引き起こすた め, 内燃機関の高効率化を図る上で最良の方法とは一概に は言いがたい

本研究では，着火運転時の機関壁面への熱流束を計測す る熱流束計を，数種類製作し鉄製定容燃焼容器を用い，予 混合気を燃焼させ定量的な熱流束検定を行うことで，熱流 束計の信頼性向上と熱流束計測の精度向上を図り，エンジ ンの熱流束計測に用いる熱流束計の検討を行う。

\section{2. 就流東垶の精度向上}

\section{1 热流束計}

図 1 に定容燃焼容器の熱流束計測に使用した熱流束計の稢 造を示す。

熱流束計の本体は $\phi 3.2 \mathrm{~mm}$ のコンスタンタン製丸棒の両 端を平行な平面に仕上げた長さ10 mmの垂直円柱である. この本体の片側端面より中心軸に平行で深さの異なる $2 つ$ の小孔 $\mathrm{a}, \mathrm{b}$ が設けられている. 表面接点は小孔 a (貫通 穴）,アース用として小孔 bにコンスタンタン素線を挿入 し, 銅素線と対をなしている. この熱電対から得られる熱 起電力から表面接点温度が求められる. なお, 表面接点は, 厚さ10 $\mu \mathrm{m}$ の電解銅メッキを全体に施すことで形成した。

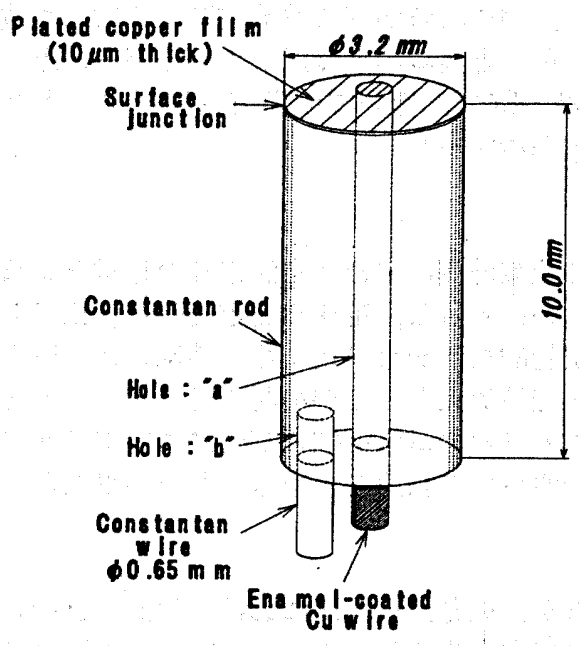

Fig.1 Structure of heat flux probe
Table 1 Types of heat flux probes

\begin{tabular}{|c|c|c|c|}
\hline Type & Probe body & Wire & Negative leg \\
\hline (1)Alu-Chr (Chr) & Chroml & Alumel & Alumel \\
\hline (2)Fe-Chr (Chr) & Chroml & Iron & Iron \\
\hline
\end{tabular}

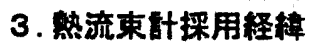

前回の絶対值検定実験報告結果 1) より，鉄母材の鉄コン スタンタン熱流束計, コンスタンタン母材のコンスタンタ ン一鉄熱流束計の結果において相違が見られた。鉄母材 鉄ーコンスタンタン熱流束計は，立ち上がりからピーク值 までガス側熱流束に良い一致を示したが，減衰が進むにつ れてガス側熱流束から離れていき，ガス側熱流束を下回る という結果を得た。一方, コンスタンタン母材のコンスタ ンタンー鉄熱流束計は, ガス側熱流束減衰開始時に比較的 近い值を示しているが, 減衰が進むにつれてガス側熱流束 を上回り，差が大きくなっていくという結果を得た.この 違いは，熱流束計が単純な熱電対であると考えると，単に 母材と素線を入れ換えただけであるため，このような差が 出るのは考えにくい，そこで，本報告ではこの差が母材と 素線の電気抵抗值の違いであることに着目し，母材と素線 の電気抵抗值を近づけスス側熱流束波形との比較検討を 行った．本報告では表 1 に示すような 2 種の熱流束計を製 作した.

\section{1 クロメル母材のアルメルークロメル就流束胡}

過去の実験において，アルメル母材のアルメルークロメ ル熱流束計を負側の物性で計算したにもかかわらず，銅一 コンスタンタン熱流束計に比へ壁側熱流束のピーク值が約 1.4倍大きくなるという結果であった. コンスタンタン母. 材のコンスタンタン一鉄熱流束計と鉄母材の鉄ーコンスタ ンタン熱流束計では，電気抵抗值の割合が離れていたため， 電気抵抗値の割合に着目した.

そこで，過去の実験"にたおいて製作したアルメル母材の アルメルークロメル熱流束計の母材と素線の電気抵抗をみ なおしたところ，母材に使用しているアルメルの電気抵抗 值が素線のクロメルの電気抵抗值に比べさかった. よっ て，本報告では，クロメル母材のアルメルークロメル熱流 束計を製作し，母材と素線を入れ換えることによる電気抵 抗值の変化による壁側熱流束に与える影響を検討するため に製作した.

3. 2 クロメル母材の铁ークロメル熱流東㣌 一般的 には，熱流束計は測定対象物の材質を使用したほうが良い といわれている゙2ため, エンジンと材質が同じである鉄を 使用している熱流束計を製作することで電気抵抗値の割合 の変化を見た，また、コンスタンタン母材銅ーコンスタン タン熟流束計の壁側熟流束波形と同様な結果が得られたな 
ら，熱流束計に用いる材質は，どの組み合わせでも良いと いえる. そこで，素線の材質が同じで，母材の材質が違う コンスタンタン母材のコンスタンタンー铁熱流束計，及び 母材の材質が同じで，素線の材質が違らクロメル母材アル

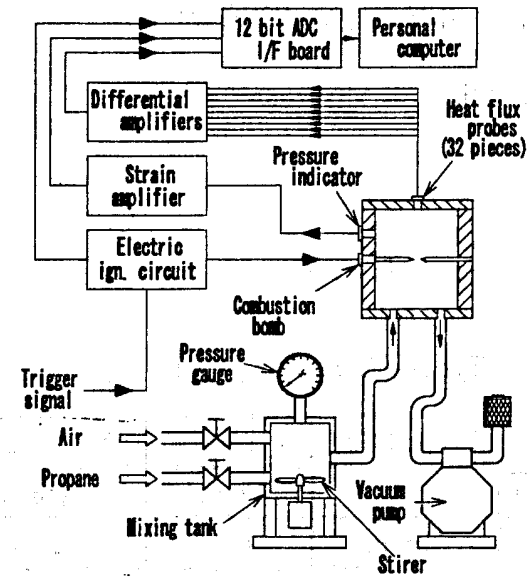

Fig.2 Quantitative Measurement system

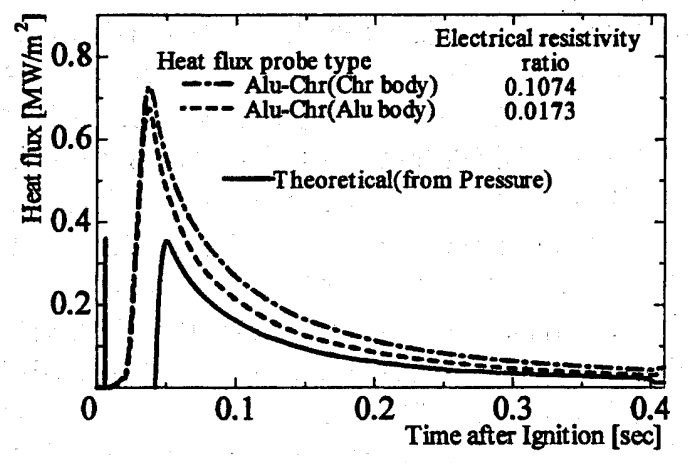

Fig.3 Calculation results of probe (Type (1))

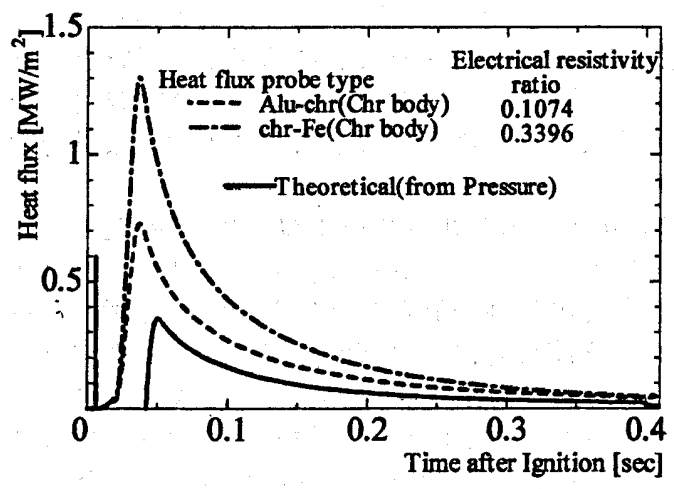

Fig.4 Calculation results of two kinds of probe (Probe body same material)

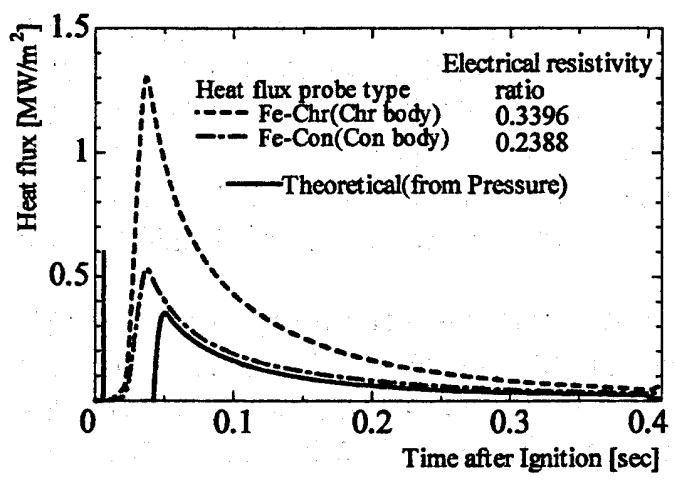

Fig.5 Calculation results of two kinds of probe (Wire same material)
メルークロメル熱流束計との電気抵抗值の割合の比較を行 うためこの熱流束計を製作した。

\section{4 絶対值検定}

図 2 に絶対值検定（定量的検定）システムを示す。こ の絶対值検定は, 予め予混合気生成タンクにてプロパンと 空気を当量比 1 にて混合, 生成し, それを定容燃焼容器に 充填圧0.1MPaで注入し, 容器中心にて火花点火により燃 焼をさせた. その際, 同時に容器内圧力と, 容器に32䇫所 取り付けられた熱流束計から表面温度をサンプリング間隔 $200 \mu$ sで2048データを計測した。

計測された圧力波形から熱力学第一法則より算出される 燃焼終了後における容器全体の熱流束（以後, ガス敗熱流 束）を基淮值とし，熱流束計表面温度から各計測点の熱流 束が算出され各計測点の熱流束計が出力する熱流束に代表 面積を掛け合わせ，その総和を燃焼室壁面の総面積で除し た熱流束 (以後, 壁側熱流束)，を比較することで，熱流束 計に評価を与えるものである. 燃焼状烲にあるピーク地点 以前では熱発生と熱損失が同時に発生する為, 評価区間は ガス側熱流束波形より判断できる燃焼が終了し単純な熱損 失の状態と考えられる減衰過程とした.

\section{4. 棅色対值検定結果}

4.1 再現性 前回と今回の圧力波形・ガス側熱流束 を比較した. ガス側熱流束の圧力波形および熱流束波形は 一致していたため, 再現性が確保できていた。

\section{2 電気抵抗值の割合（壁側繁流束）}

4.2.1 アルメルークロメル鶖流束計母材と素線 を入れ換えて比較した熱流束波形を図 3 に示す。母材と 素線の電気抵抗の割合が 1 に近い方のアルメルークロメ ル熱流束波形が，割合の低い方の熱流束波形より大きく なっていることがわかった.

4.2.2 クロメル母材のアルメルークロメル熱流束勘・ クロメル母材の铁ークロメル鶖流東胡 母材の材質が 同じで，素線の材質が異なる熱流束計を比較した波形を図 4 に示す. 母材と素線の電気抵抗の割合が 1 に近い方の熱 流束波形が, 割合の低い方の熱流束波形より大きくなって いることがわかった.

4. 2. 3 コンスタンタン母材のコンスタンタンー铁欮流 束計・クロメル母材の铁一クロメル就流東就 母材の 材質が異なり，素線の材質が同じ熱流束計を比較した波形 を図 5 に示す. 母材と素線の電気抵抗の割合が 1 に近い方 の熱流束波形が，割合の低い方の熱流束波形より大きく なっていることがわかった.

\section{5. 結諭}

エンジンの熱流束計測に用いる熱流束計の母材と素線の 電気抵抗値の違いに着目し, 定容燃焼容器内で静止予混合 気を燃焼させ定量的な熱流束検定を行い燃焼ガスの圧力よ り算出したガス側熱流束との比較検討を行った。この結果, 熱流束計の母材と素線の電気抵抗の割合については熱流束 計測の結果との明らかな相関を求めることが出来なかった。

\section{参考文献}

1）長瀬慶紀ほか，火花点火機関における熱流束計測の精 度向上（日本機械学会講演論文集 No.028-1）P189， 2002

2) 榎本良猶ほか, 内燃機関の燃焼室表面瞬間温度测定用 熱電対に関する研究 機論B編, 50巻, 453号, P13531364,1984 